\title{
METODE PENGAJARAN KARAKTER YANG DIGUNAKAN RASULULLAH SAW. KEPADA PARA SHAHABAT DALAM KITAB SHAHIH MUSLIM
}

\section{Taufik Abdillah Syukur}

Universitas Islam Negeri Syarif Hidayatullah Jakarta abdillah2803@gmail.com

\section{Abstract}

The research is talking about the prophet teaching method in building his companions character according to Shaheeh Muslim. And that result will explain about the complementation of prophet teaching method in shaping student character in the school.

This study depends on the sourced literature. The researcher qualitatively collects data, describes and analyzes it well. This research is about the character teaching method depends on the prophetic tradition (al-Hadits). The researcher classifies the hadits based on nation character, analyzes that results and relates things with the main project.

The result indicates that the most widely used method of the prophet in shaping his companions character is the method of story, question \& answer, and also lecturer. He also used another variety method such as problem solving, assignment, demonstration and fieldtrip. In shaping his companions character he did not use the method of discussion, experiment, and project.

Researcher recommends all teachers to control and widely explore those three methods (stories, discussion, and lecturer) and integrate love, friends/ communicative, and care character as the main student character in process character education at school.

Keywords: Prophet, Teaching method, Character, Shaheeh Muslim 


\section{Abstrak}

Penelitian ini membahas tentang tentang metode pengajaran karakter yang digunakan Rasulullah SAW. kepada para shahabat dalam kitab Shahih Muslim dan implementasinya dalam pendidikan karakter di sekolah.

Penelitian ini menggunakan kajian pustaka yang bersumber dari kepustakaan. Peneliti mengumpulkan data yang bercorak kualitatif yang dideskripsikan untuk kemudian dianalisis. Penelitian ini seputar masalah metode pengajaran karakter yang mengambil hadits sebagaipijakannya.Adapun untukmenganalisa masalah, peneliti mengklasifikasikan hadits-hadits berdasarkan teori pendidikan karakter dan metode pengajaran. Kemudian menganalisis hasil klasifikasi tersebut dan menghubungkannya dengan pokok pembahasan.

Hasil penelitian ini ditemukan bahwa metode yang paling banyak digunakan Rasulullah SAW. dalam pendidikan karakter shahabat adalah metode cerita, tanya jawab dan ceramah. Rasulullah SAW. juga menggunakan metode lain walaupun tidak banyak seperti pemecahan masalah, penugasan, demostrasi dan karyawisata. Rasulullah SAW. tidak menggunakan metode diskusi, eksperimen dan proyek dalam pendidikan karakter shahabat.

Peneliti merekomendasikan agar para guru pengampu pendidikan karakter untuk menguasai tiga metode pengajaran yaitu cerita, tanya jawab dan ceramah serta mengintegrasikan karakter cinta, bersahabat/komunikatif dan peduli dalam proses pendidikan karakter di sekolah.

Kata Kunci: Nabi, Metode pengajaran, Karakter, Shahih Muslim 


\section{A. PENDAHULUAN}

- ejarah mencatat bahwa tidak ada prestasi dalam bidang pendidikan paling cemerlang yang pernah terjadi di muka bumi ini melainkan keberhasilan konsep pendidikan Rasulullah SAW., yang mampu mengubah dari tradisi ke-jahiliyahan kepada Islam. ${ }^{1}$

Rasulullah SAW. telah berhasil mendidik sahabatnya menjadi masyarakat muslim yang berkualitas dan berkarakter. Mereka rindu akan kebenaran, semangat dalam menuntut ilmu, merasa mulia dengan Islam, sederhana dalam sikap, ketika malam hari mereka menangis ber-taqarrub kepada Allah Swt, di siang hari mereka berjihad melawan kemusyrikan, kekafiran dan kezaliman, memerintahkan kepada kebaikan dan melarang dari kejahatan serta menebarkan kasih sayang dengan menghilangkan bebanbeban kaum muslimin. ${ }^{2}$

Mereka saling kasih mengasihi, cinta mencintai sesama kaum muslimin. Sebagaimana firman Allah Swt:

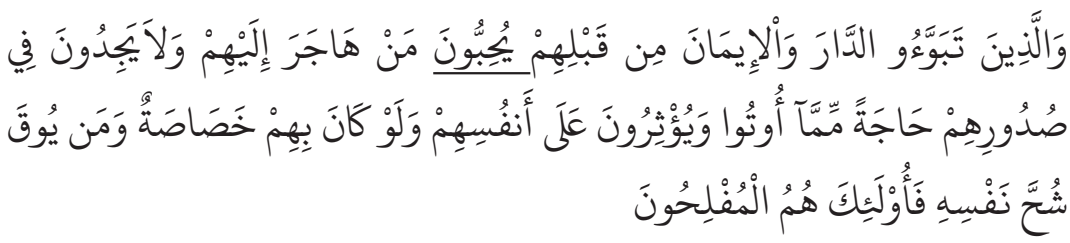

"Orang-orang yang telah menempati kota Madinah dan telah beriman (Anshor) sebelum (kedatangan) mereka (Muhajirin), mereka (Anshor) «mencintai orang yang berhijrah kepada mereka (Muhajirin). dan mereka (Anshor) tiada menaruh keinginan dalam hati mereka terhadap apa-apa yang diberikan kepada mereka (Muhajirin); dan mereka mengutamakan (orang-orang muhajirin), atas diri mereka sendiri, sekalipun mereka dalam kesusahan. dan siapa yang dipelihara dari kekikiran dirinya, mereka itulah orang orang yang beruntung." (QS. alHasyr: 9).

1 Ulil Amri Syafri, Pendidikan Karakter Berbasis al-Qur'an, Jakarta: PT RajaGrafindo Persada, 2012, cet. ke-1, h. 145.

2 Sofyan Sauri, Filsafat dan teosofat Akhlak (kajian filosofis dan teosofis tentang akhlak, karakter, nilai, moral, etika, budi pekerti, tatakrama, dan sopa santun), (Bandung: Rizqi Press, 2011), h.135. 
Allah menerangkan sifat-sifat orang Muhajirin sebagai berikut:

a. Orang-orang yang beriman kepada Allah dan Rasul-Nya, mereka menunjukkan ketaatan mereka hanya kepada Allah saja dengan mengorbankan semua yang mereka miliki hanya untuk mencari keridhaan-Nya.

b. Orang-orang yang rela meninggalkan rumah dan harta bendanya untuk melaksanakan perintah Allah Swt dan RasulNya.

c. Orang-orang yang berani mengorbankan jiwa dan raganya untuk membela Allah Swt dan Rasul-Nya.

Ayat ini juga menerangkan sikap orang-orang Anshar:

a. Mereka mencintai orang-orang Muhajirin, dan menginginkan agar orang Muhajirin itu memperoleh kebaikan sebagaimana mereka menginginkan kebaikan untuk dirinya.

b. Orang Anshar tidak berkeinginan memperoleh harta fa'i itu seperti yang telah diberikan kepada kaum Muhajirin. Pada akhir ayat ini dijelaskan bahwa orang-orang tersebut dalam ayat 10 ini mengatakan bahwa Allah Maha Penyayang kepada para hamba-Nya dan banyak melimpahkan rahmat-Nya. Oleh karena itu, mereka mohon agar Dia memperkenankan doa-doa mereka. $^{3}$

Allah Swt juga menggambarkan sosok para sahabat sebagai karakter-karakter yang saling memegang komitmen, saling menyayangi, saling membantu, giat beribadah, dan menghabiskan waktu demi menggapai ridha-Nya. Hal itu sebagaimana tercantum dalam firman Allah Swt:

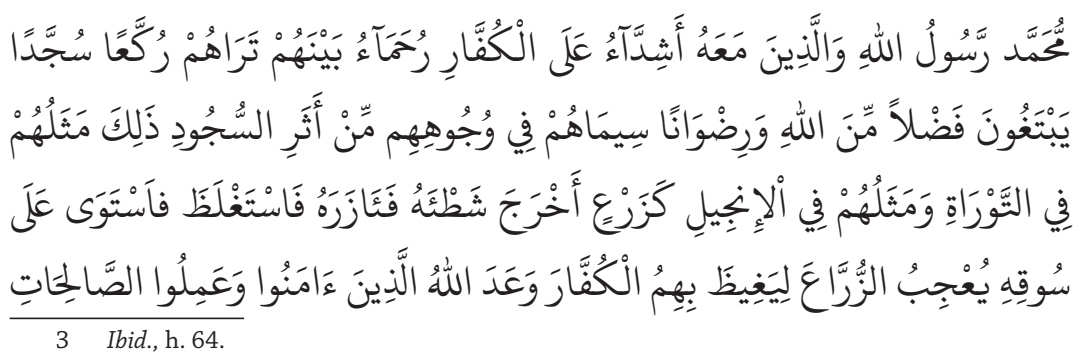




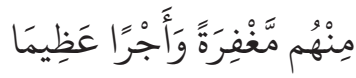

"Muhammad itu adalah utusan Allah dan orang-orang yang bersama dengan dia adalah keras terhadap orang-orang kafir, tetapi berkasih sayang sesama mereka. kamu lihat mereka ruku' dan sujud mencari karunia Allah dan keridhaan-Nya, tanda-tanda mereka tampak pada muka mereka dari bekas sujud. Demikianlah sifat-sifat mereka dalam Taurat dan sifat-sifat mereka dalam Injil, yaitu seperti tanaman yang mengeluarkan tunasnya maka tunas itu menjadikan tanaman itu kuat lalu menjadi besarlah dia dan tegak lurus di atas pokoknya; tanaman itu menyenangkan hati penanam-penanamnya karena Allah hendak menjengkelkan hati orang-orang kafir (dengan kekuatan orang-orang mukmin). Allah menjanjikan kepada orang-orang yang beriman dan mengerjakan amal yang saleh di antara mereka ampunan dan pahala yang besar," (QS. al-Fath [48]: 29). ${ }^{4}$

Di Indonesia, masalah pendidikan karakter saat ini masih menjadi pembicaraan di seminar-seminar hingga penataran guru. Karena banyak yang menyadari pendidikan karakter di Indonesia masih belum seberhasil pengajaran ilmu pengetahuan dan keterampilan.

Indonesia pernah meraih penghargaan dengan menjadi juara umum dalam International Conference of Young Scientists (ICYS) atau Konferensi Internasional Ilmuwan Muda se-Dunia yang diikuti ratusan pelajar SMA dari 19 negara di Bali pada 12-17 April 2010. Pada bulan Mei 2012, banyak siswa Indonesia yang menang dalam ajang Olimpiade Iptek International, International Sustainable World Energy, Engineering \& Environment Project Olympiade, I-SWEEEP 2012 yang diselenggarakan di Houston, Amerika Serikat. Enam siswa Indonesia memboyong medali emas, perak dan perunggu dari 600 orang peserta yang berasal dari 68 negara. Suatu prestasi yang membanggakan dalam bidang ilmu pengetahuan.

Begitu juga dalam bidang keterampilan. Banyak prestasi yang ditorehkan anak-anak SMK khususnya, dari membuat mobil

4 Departemen Agama, Al-Qur'an dan Tafsirnya, Jakarta: Departemen Agama RI, 2009, jilid 9, h. 391 . 
hingga pesawat. Kabar terbaru datang dari wilayah Indonesia tengah, tepatnya dari SMK Negeri 3 Mataram. Siswa di SMK ini telah merakit 2.000 komputer jinjing atau laptop untuk memenuhi kebutuhan beberapa sekolah di Nusa Tenggara Barat (NTB). ${ }^{5}$

Tetapi berita dan kegemilangan siswa-siswi Indonesia itu seakan tenggelam dengan berbagai tayangan-tayangan kekerasan yang ironisnya berasal dari dunia pendidikan. Di Makassar para mahasiswa bertindak anarkis dengan membakar dua pos polisi dan membakar ban. Di Ambon akhir April lalu para mahasiswa bentrok dengan pejabat kampus. Kekerasan dalam dunia pendidikan seakan menjadi tradisi di negara kita, mulai dari senioritas sampai tawuran ${ }^{6}$ dari tingkat pelajar sampai mahasiswa.

Tawuran pelajar sekolah menjadi potret buram dalam dunia pendidikan Indonesia. Pada 2010, setidaknya terjadi 128 kasus tawuran antar pelajar. Angka itu melonjak tajam lebih dari $100 \%$ pada 2011, yakni 330 kasus tawuran yang menewaskan 82 pelajar. $^{7}$

Ternyata, hal-hal negatif yang muncul dalam dunia pendidikan bukan hanya tawuran, kekerasan, dan senioritas saja tetapi kebiasaan para pelajar mencorat-coret bangku dan meja kelas, tembok sekolah dan rumah penduduk, bahkan fasilitas umum. Belum lagi berbicara kasar dan jorok seperti memanggil orang dengan nama binatang, mengejek nama ayah ibunya atau sesuatu yang dapat menyakiti perasaan temannya dengan sebutan bodoh dan lain sebagainya, sehingga menunjukkan lemahnya budaya bahasa santun ${ }^{8}$ dalam lingkungan pelajar di sekolah.

Berbagai peristiwa yang disaksikan melalui televisi, media cetak maupun media elektronik menunjukkan betapa masyarakat Indonesia masih mengalami degradasi moral. Betapa tidak, kasus korupsi masih merajalela bahkan dilakukan secara berjama'ah dan

5 http://mizan.com/news_det/wow-anak-smk-di-mataram-jago-merakit-laptop-and-lcd. html 10 Maret 2013 20:00 WIB

6 Tawuran atau perkelahian pelajar adalah salah satu bentuk kenakalan remaja. Lihat Amal Fatkhullah, Tawuran Pelajar, dalam Abudin Nata, Kapita Selekta Pendidikan Islam,(Bandung: Penerbit Angkasa, 2003), h. 191.

7 http://m.tvonenews.tv / read.htmlid=62132 27/09/2012 12:44 WIB

8 Lihat Sofyan Sauri, Pendidikan Berbahasa Santun, Bandung: PT Genesindo, 2006, h. 7 
kasus perselingkuhan yang dilakukan oleh public figure. ${ }^{9}$ Anehnya terhadap kasus perselingkuhan tersebut sebagian masyarakat menyikapinya biasa-biasa saja.

Sanksi sosial terkadang tidak berlaku lagi dan cenderung membiarkan, bahkan apatis. Lebih tragis lagi petugas keamanan seperti polisi justru menjadi sasaran kekerasan bahkan pembunuhan. Para petugas hukum malah yang melanggar hukum, hakim yang tugasnya menjadi benteng penegak keadilan justru mempertontonkan praktik ketidakadilan. Kampus sebagai tempat para intelektual yang seharusnya menjunjung nilai-nilai kemanusiaan yang tinggi dan menjauhi anarkisme juga tak luput dari aksi anarkis seperti perusakan laboratorium, ruang kuliah dan perkantoran. Intelektual yang mestinya mengedepankan argumentasi dengan nalar logis dalam menyelesaikan persoalan seolah melupakan etika akademik yang menjadi bagian kehidupannya. Semua menjadi tontonan yang memilukan.

Hal-halyang dipaparkan diatas menunjukkan bahwa pendidikan di Indonesia masih belum berhasil mendidik siswa menjadi siswa yang berkarakter sebagaimana yang diharapkan.

Yang menjadi pertanyaan adalah apakah mentalitas ini disebabkan karena kerusakan individu-individu yang kemudian terjadi secara kolektif atau justru merupakan kegagalan pendidikan dalam mendidik siswa menjadi manusia yang berkarakter?. ${ }^{10}$

Bukankah pendidikan agama dan pancasila telah diajarkan sejak sekolah dasar hingga perguruan tinggi? Bukankah pendidikan tersebut juga telah ditatarkan kepada pejabat tinggi negara, pegawai negeri sipil (PNS) bahkan organisasi kemasyarakatan.

Kalau begitu, adakah cara lain selain pendidikan dalam membangun karakter bangsa ini?. Misalnya melalui politik atau kegiatan ekonomi. Jawabannya mungkin bisa, tetapi pendidikan merupakan jalan yang terbaik untuk membangun karakter bangsa ini, bahkan untuk membangun sebuah peradaban.

9 Lihat juga Wendi Zarman, Ternyata Mendidik Anak Cara Rasulullah itu Mudah dan Lebih Efektif, (Jakarta: Penerbit Ruang Kata, 2011), h. 30.

10 Wendi Zarman, Ternyata Mendidik Anak Cara Rasulullah itu Mudah dan Lebih Efektif, Jakarta: Penerbit Ruang Kata, 2011, h. 32 - 34. 
Hanya saja konsep pendidikan saat ini harus ditinjau kembali. Kenapa demikian, karena masih banyak peristiwa negatif yang justru datang dari dunia pendidikan. Seperti menyontek massal saat Ujian Nasional, meningkatnya jumlah pemakai narkoba dan seks bebas pada usia sekolah, belum lagi persoalan pada lulusan sekolah yang terjebak pada pengangguran, pemalas, tidak kreatif, dan lain sebagainya, yang menunjukkan lemahnya karakter bangsa.

Pemerintah Republik Indonesia melalui Kementerian Pendidikan dan Kebudayaan dan Kementrian Agama Republik Indonesia, telah mengintruksikan kepada setiap sekolah agar memasukkan pendidikan karakter pada Kurikulum Tingkat Satuan Pendidikan (KTSP), Silabus dan Rencana Pelaksanaan Pembelajaran (RPP).

Hal itu dilandasi oleh Undang-undang nomor 20/2003 tentang Sistem Pendidikan Nasional, Permendiknas nomor 22/2006 tentang Standar Isi, Permendiknas nomor 23/2006 tentang SKL, Inpres nomor 1/2010 tentang Percepatan Pelaksanaan Prioritas Pembangunan Nasional Tahun 2010 menyatakan/menghendaki/ memerintahkan pengembangan karakter peserta didik melalui pendidikan di sekolah.

Undang-undang Sistem Pendidikan Nasional pasal 3 menyebutkan: 1) Pendidikan Nasional mengembangkan kemampuan dan membentuk karakter serta peradaban bangsa yang bermartabat dalam rangka mencerdaskan kehidupan bangsa. 2) Pendidikan Nasional bertujuan untuk berkembangnya potensi peserta didik agar menjadi manusia yang beriman dan bertakwa kepada Tuhan Yang Maha Esa, berakhlak mulia, sehat, berilmu, cakap, kreatif, mandiri dan menjadi warga negara yang demokratis serta bertanggung jawab.

Nilai karakter yang telah ditetapkan oleh Kementerian Pendidikan Nasional Republik Indonesia sebagai berikut: religius, jujur, toleransi, disiplin, kerja keras, kreatif, mandiri, demokratis, rasa ingin tahu, semangat kebangsaan, cinta tanah air, menghargai prestasi, bersahabat/ komunikatif, cinta damai, gemar membaca, peduli lingkungan, peduli sosial, dan tanggung jawab. ${ }^{11}$

11 Erry Utowo et. Al., Pengembangan pendidikan Budaya dan Karakter Bangsa, Jakarta: Pusat 
Dari kebijakan di atas, Pemerintah berharap agar sekolah mampu mengantarkan siswa menjadi manusia yang berkarakter. ${ }^{12}$ Jika harapan ataupun tujuan tersebut tidak tercapai maka ada sesuatu yang salah dalam penyelenggaraan pendidikan, apakah itu kurikulum, metode pengajaran, kualitas guru, keadaan siswa, fasilitas sekolah, atau yang lainnya. Maka perlu diadakan evaluasi, pembenahan dan peningkatan kualitas di setiap lini.

Pembenahan bukan berarti merombak penyelenggaraan pendidikan secara keseluruhan atau merubah kurikulum tingkat nasional seperti kurikulum 2013 yang saat ini sedang disosialisasikan. Tetapi, salah satunya dengan peningkatan kualitas guru dengan memberikan pelatihan guru tentang metode pengajaran. ${ }^{13}$

Sebagaimana Inpres Nomor 1 Tahun 2010. Bidang pendidikan tentang Penguatan metodologi dan kurikulum. 1) Penyempurnaan kurikulum dan metode pembelajaran aktif berdasarkan nilai-nilai budaya bangsa untuk membentuk daya saing dan karakter bangsa. 2) Terselenggaranya uji coba kurikulum dan metode pembelajaran aktif berdasarkan nilai-nilai budaya bangsa untuk membentuk daya saing dan karakter bangsa. ${ }^{14}$ Berdasarkan Inpres inilah pertanda urgensi metodologi pengajaran dalam pendidikan karakter bangsa.

Banyak metode dan gaya mengajar guru yang tidak disukai siswa. Jika metode dan gaya mengajar guru disukai siswa, maka tidak ada siswa yang bodoh, tidak ada pelajaran yang sulit dan tidak ada pelajaran yang membosankan. Justru yang ada hanyalah guru yang membosankan. Paradigma lama yang salah adalah jika guru mengajar kemudian siswa tidak mengerti, maka yang salah adalah siswa, kenapa mereka tidak mengerti? ${ }^{15}$

\footnotetext{
Kurikulum Kementrian Pendidikan Nasional, 2010, h. 7-10.

12 Abd al-Rahman Abd al-Khiq, al-Fikr al-Shufi fi Dhau al-Kitab wa al-Sunnah, (Kuwait: Maktabah Ibn Taimiyah, 1986), cet. ke-3, h. 316-349.

13 Abuddin Nata, Perspektif Islam tentang Strategi Pembelajaran, (Jakarta: Kencana Prenada Media Group, 2009), cet. ke-1, h. 174

14 Materi Pelatihan Peningkatan Manajemen Melalui Penguatan Tata Kelola dan Akuntabilitas di Sekolah/Madrasah, Jakarta: kementrian Pendidikan Nasional dan Kementrian Agama RI, 2012, h. 243-245.

15 Siswa yang tidak mengerti dan tidak semangat lagi, terapinya harus sering dicium, disentuh, dipeluk, dan diusap kepalanya. Lihat, Wendi Zarman, Mendidik Anak Cara Rasulullah, Bandung:
} 
Dalam proses belajar mengajar, guru biasanya menggunakan metode ceramah, tanya jawab, cerita, diskusi, demonstrasi, penugasan, pemecahan masalah, karyawisata, eksperimen, proyek dan lain-lain. ${ }^{16}$ Metode pengajaran ini akan terus bertambah sejalan dengan kemajuan perkembangan teori-teori pengajaran. ${ }^{17}$

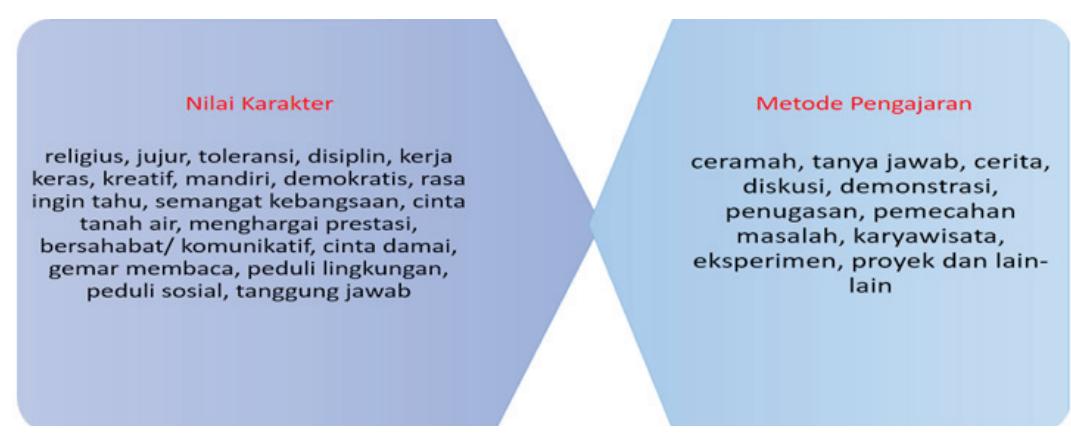

Gambar 1

Nilai Karakter dan Metode Pengajaran

Nilai-nilai karakter yang ditetapkan Pemerintah itu baik dan sifatnya universal. Begitu juga, metode pengajaran yang ditetapkan oleh guru dalam RPP juga baik. Yang jadi permasalahan adalah kenapa dengan metode pengajaran yang baik masih belum bisa menjadikan siswa dan lulusannya menjadi manusia yang berkarakter? ${ }^{18}$

Padahal pemerintah telah mengalokasikan dana Bantuan Operasional Sekolah (BOS) untuk peningkatan kualitas guru, diantaranya dengan pelatihan guru terkait dengan metode pengajaran dan pendidikan karakter. ${ }^{19}$

Sepertinya guru harus diperlihatkan metode yang sudah lama terbukti keunggulannya dalam mendidik manusia berkarakter

Penerbit Ruang Kata, 2011, cet. ke-1, h. 163.

16 Aminuddin Rasyad, Teori Belajar dan Pembelajaran, (Jakarta: Uhamka Press, 2003), cet. ke 4, h. $109-110$.

17 Ahmad Tafsir, Ilmu Pendidikan dalam Perspektif Islam, (Bandung: Penerbit PT Remaja Rosdakarya, 2010), cet, 9, h. 131

18 Ahmad Tafsir, Ilmu Pendidikan dalam Perspektif Islam, (Bandung: Penerbit PT Remaja Rosdakarya, 2010), cet, 9, h. 131

19 Peningkatan Manajemen Melalui Penguatan Tata Kelola dan Akuntabilitas di Sekolah/Madrasah, Jakarta: Kementrian Pendidikan Nasional dan Kementrian Agama RI, 2011, h. 135. 
tetapi metode itu seolah-olah lenyap dengan adanya metode barat. Metode itu adalah metode pengajaran karakter oleh Rasulullah SAW. kepada para shahabat.

Melihat keberhasilan Rasulullah SAW. dalam mendidik sahabat, maka penulis merasa perlu untuk melakukan revitalisasi metode pengajaran karakter yang dilakukan Rasulullah SAW. kepada para shahabat. Metode pengajaran karakter itu perlu diungkap dan dikaji kembali sebagai sumber ide, gagasan, inspirasi dan bahan perbandingan dengan metode pengajaran kontemporer. ${ }^{20}$

Untuk menggali lebih dalam lagi metode pengajaran karakter itu, maka perlu diadakan kajian secara menyeluruh tentang haditshadits yang terkait dengan pendidikan karakter sahabat. Haditshadits itu harus dilihat secara utuh dari kitab-kitab hadits shahih yang diakui para ulama. Penulis memilih Shahih Muslim untuk dikaji karena beberapa alasan. Diantaranya adalah susunan Shahih Muslim lebih sitematis di banding Shahih Bukhari. Karena haditshadits dihimpun di dalamnya berdasarkan bab-bab yang ada dalam kitab fikih. Dengan demikian, bagi seseorang yang ingin meneliti hadits, lebih mudah menelusurinya dalam kitab Shahih Muslim. ${ }^{21}$ Kemudian, di dalam Shahih Muslim terdapat kitab adab. ${ }^{22}$ Judul kitab ini, menurut hemat penulis lebih mendekati kepada pendidikan karakter yang dimaksud oleh pemerintah Republik Indonesia.

Untuk memudahkan penelitian, penulis tidak meneliti seluruh hadits dalam Shahih Muslim. Tetapi hanya memfokuskan pada kitab adab yang terdiri dari 51 bab 73 hadits. Diharapkan nantinya dapat ditemukan metode pengajaran karakter yang paling efektif digunakan Rasulullah SAW. dan dapat di implementasikan di sekolah.

20 Samsul Nizar (ed), Sejarah Pendidikan Islam (Menelusuri Jejak Sejarah Pendidikan Era Rasulullah Sampai Indonesia), Jakarta: Kencana, 2009, cet. ke-3, h.1.

21 Muhammad Alfis C, Indeks Hadits dan Syarah, Jakarta: CV. Alfonso Pratama, 2008, h. 24-25.

22 Kafrawi Ridwan, Ensiklopedi Islam, Jakarta: PT Ikhtiar Baru Van Hoeve, 1994, h. 57. 


\section{B. PEMBAHASAN}

Hasil penelitian hadits-hadits Shahih Muslim berdasarkan nilai pendidikan karakter sebagai berikut: Karakter cinta damai 21 hadits, bersahabat/komunikatif 11 hadits, peduli sosial 9 hadits, peduli lingkungan 7 hadits, kejujuran 4 hadits, religiusitas 4 hadits, menghargai prestasi 2 hadits, rasa ingin tahu 2 hadits, toleransi 1 hadits, semangat kebangsaan 1 hadits, sabar 8 hadits, dan rendah hati 3 hadits.

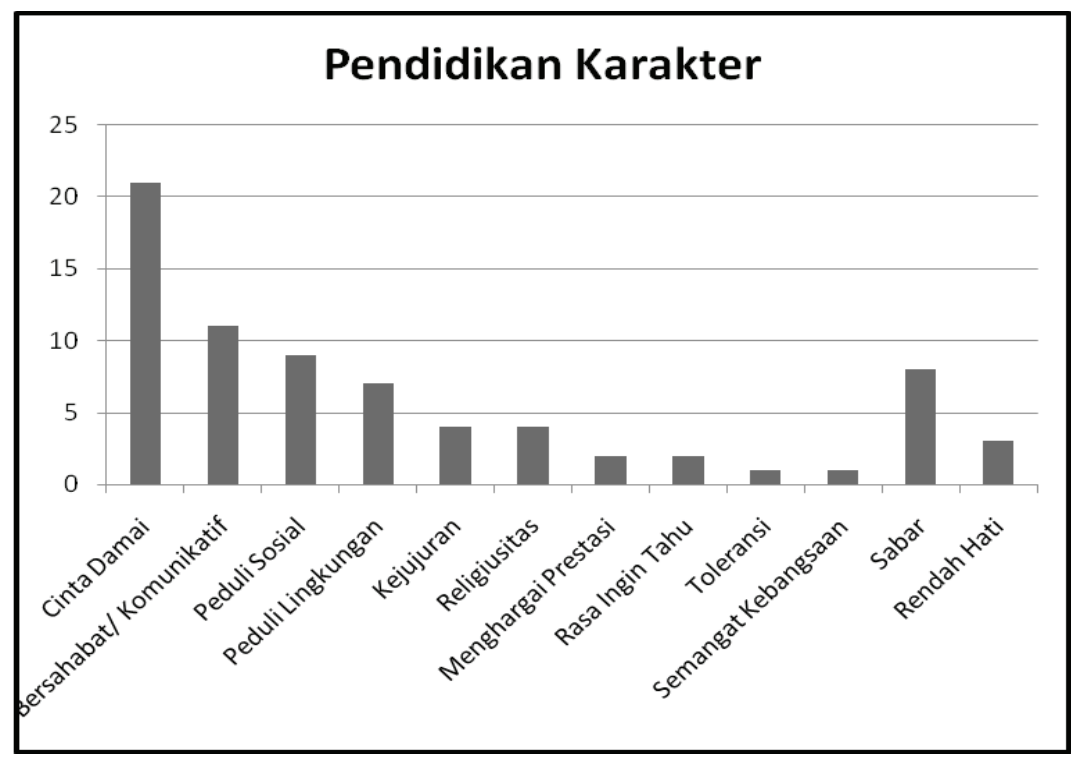

Gambar 2

Pendidikan Karakter

Dari penelitian ini, diperoleh data bahwa pembentukan beberapa nilai karakter seperti disiplin, kreativitas, kerja keras, kemandirian, demokratis, cinta tanah air, tanggung jawab dan senang membaca, tidak ditemukan dalam kajian bab kebajikan, silaturahim dan adab dalam kitab shahih Muslim ini. Ada pula bebarapa karakter tidak dominan dalam kitab ini, tetapi mungkin di kitab lain menjadi paling dominan. Seperti religiusitas akan banyak di dapati di kitab iman dan rasa ingin tahu pada kitab ilmu. ${ }^{23}$

23 Lihat Shahih Muslim, hadis nomor 3399, 625, 3635, dan 1332. 
Ada dua nilai karakter yang tidak ditetapkan oleh pemerintah RI, tetapi ada dalam kajian ini yaitu sabar dan rendah hati. Penelitian ini juga memperoleh data bahwa pembentukan karakter yang paling banyak diharapkan dari shahabat Rasulullah SAW. adalah karakter cinta damai, bersahabat/ komunikatif, peduli sosial dan peduli lingkungan.

Untuk lebih memahami hadits-hadits Rasulullah SAW. dalam kajian adab kitab Shahih Muslim, maka penulis menyingkat empat karakter dominan tersebut dengan tiga singkatan yaitu 'cinta, bersahabat dan peduli'. Cinta damai dengan cinta, bersahabat/ komunikatif dengan bersahabat dan peduli sosial dan lingkungan dengan peduli.

\section{Esensi Kitab Adab}

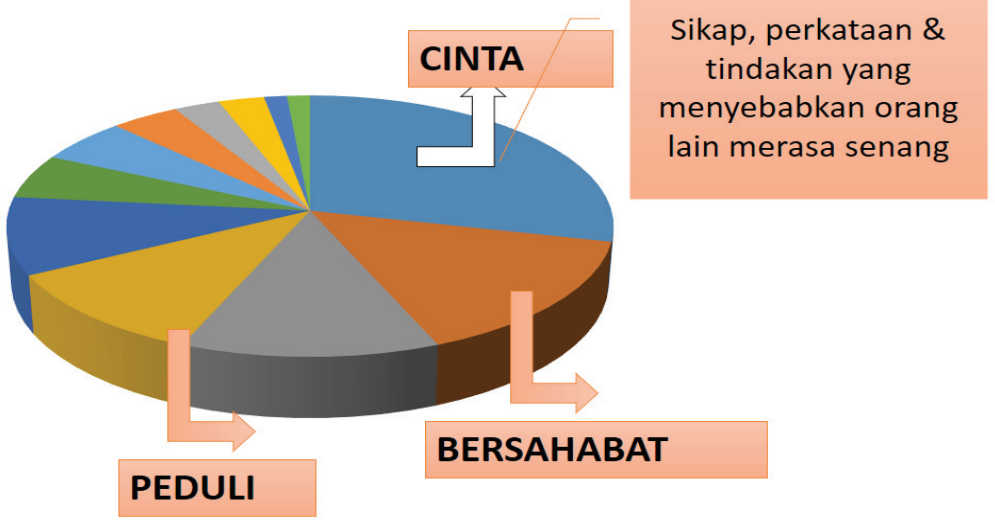

Gambar 3

\section{Esensi Kitab Adab}

Saat ini, guru ketika menetapkan nilai karakter, baik di dalam silabus maupun RPP nampak kurang fokus. Karena jumlah karakter yang terlalu banyak yang harus di ajarkan kepada siswa menjadikan guru dan siswa bingung. Maka peneliti mengusulkan untuk fokus pada karakter cinta, bersahabat dan peduli serta menjadikannya sebagai karakter utama dalam pengajaran sedangkan karakter yang lain sebagai karakter pendukung dari karakter yang utama tersebut. 
Seluruh karakter dominan dalam kajian ini mengarah kepada satu karakter yaitu cinta damai atau cinta. Cinta damai adalah sikap, perkataan, dan tindakan yang mencerminkan kasih sayang, sehingga menyebabkan orang lain merasa senang dan aman atas kehadiran dirinya.

Jika pendidikan karakter memerlukan teladan, maka Rasulullah SAW. merupakan teladan sempurna dalam karakter cinta ini. Cinta yang diajarkan Rasulullah SAW. kepada para shahabat antara lain cinta kepada orang tua (Shahih Muslim, no. 4623), cinta kepada keluarga (Shahih Muslim, no. 4638), cinta kepada sesama muslim (Shahih Muslim, no. 4650), cinta kepada orang-orang sholeh (Shahih Muslim, no. 4762), cinta kepada anak-anak(Shahih Muslim, no. 4765), cinta kepada tetangga (Shahih Muslim, no. 4758), cinta kepada binatang (Shahih Muslim, no. 4749), cinta karena Allah (Shahih Muslim, no. 4656), cinta Allah kepada hambanya (Shahih Muslim, no. 4772), seseorang akan bersama orang yang dicintainya (Shahih Muslim, no. 4779)

Seorang siswa diharapkan menjalani hidup di dunia ini berdasarkan cinta. Baik cinta kepada orang tua, keluarga, sesama muslim, orang shalih, tetangga, anak-anak, binatang, dan lain sebagainya. Cinta semua itu hendaklah dilandasi karena kecintaan kepada Allah Swt. Karena seseorang akan bersama dengan yang cintainya. Jika Allah mencintai seseorang maka Allah menghendaki kebaikan bagi orang tersebut. Jika Allah Swt telah mencintai seorang hamba, maka Allah Swt akan membuat hamba yang lain mencintainya.

Kalau seseorang sudah cinta maka ia akan mengidolakan dan mengikutinya. Kalau seseorang sudah cinta maka ia akan selalu memikirkan dan menyebutnya berulang-ulang kali baik di lisan maupun di hati. Dengan cinta seseorang akan mengorbankan segalanya demi hal yang dicintainya. Dengan cinta seseorang akan menjadi berani (syaja'ah) untuk melindungi orang yang dicintainya.

Contohnya Ali bin Abi Thalib berani menggantikan posisi Rasulullah SAW. ditempat tidur saat kaum kafir mengepung 
rumah Rasulullah SAW., padahal itu sangat berbahaya untuk keselamatannya. Abdurrahman bin Auf berani mengorbankan 40.000 dirham perak, 40.000 dirham emas, 500 ekor kuda perang, dan 1.500 ekor unta demi membantu Rasulullah SAW. dalam perjuangannya menegakkan Agama Islam di muka bumi ini, tanpa meninggalkan sedikitpun untuk keluarganya. Abu Ubaidah bin al-Jarrah sangat cinta kepada Rasulullah SAW. sampai-sampai berani membantu Rasulullah SAW. pada suatu kejadian di perang Uhud sampai giginya copot dan ia bangga dengan gigi yang copot itu karena digunakan untuk membantu Rasulullah SAW. Thalhah bin Ubaidillah karena kecintaannya kepada Rasulullah SAW. sampai-sampai ia menjadi seorang shahabat yang berani dengan menjadikan tubuhnya sebagai tameng bagi Rasulullah SAW. dari serangan musuh, sehingga badannya terkena lebih dari tujuh puluh tikaman dan anak panah serta jari tangannya putus.

Dengan cinta itulah yang menjadikan kaum Muhajirin dan Anshar menjadi ummat yang kuat dan bersahabat, dengan cinta itulah timbul rasa peduli antar sesama dan pengorban yang tinggi baik jiwa maupun harta, dan dari sinilah Rasulullah SAW. membangun peradaban Islam.

Saat ini persaudaraan berdasarkan ukhuwah Islamiyah semakin memudar. Di Indonesia, walaupun jumlah muslimnya mayoritas, tetapi mereka terpecah-pecah, baik dalam organisasi kemasyarakatan (ormas) maupun partai politik. Sungguh mengherankan jika ada seorang muslim tidak menjalin silaturahim kepada tetangganya sesama muslim karena satu alasan yaitu beda partai atau beda ormas. Sungguh prihatin jika ada seorang muslim yang tidak mau mengunjungi orang-orang shaleh dan tidak mau menimba ilmu dari orang-orang berilmu, wara', dan tawadhu, karena satu hal yaitu beda ormas atau beda partai. Maka, Sudah saatnya umat Islam Indonesia menjadikan ukhuwah Islamiyah diatas kepentingan ormas dan partai politik.

Saat ini ummat Islam di Indonesia digiring opininya melalui media. Anak-anak pelajar saat ini salah dalam mengartikan dan menggunakan kata cinta. Mereka lebih mencintai idolanya dari 
pada mencintai gurunya. Kasus Ariel harus menjadi pelajaran bagi para guru. Di pendahuluan disertasi ini dipaparkan bagaimana seorang 'abg' menangis histeris ketika ariel dibebaskan dari penjara. Dalam penelitian ini ditemukan hadits yang berbunyi 'seseorang akan bersama dengan orang yang dicintainya.' Bahwa seseorang nanti di hari kiamat (akhirat) akan dikumpulkan bersama dengan orang yang dicintai dan diidolakannya. Jika yang ia cintai adalah orang fasiq maka ia akan bersama dengan orang fasiq, jika yang ia cintai artis maka ia akan bersama artis itu pada hari kiamat. Tapi jika yang ia cintai adalah orang-orang shaleh, Rasulullah SAW. beserta para shahabat maka ia akan dikumpukan bersama mereka pada hari kiamat.

Dengan cinta maka karakter yang lain akan mengikuti dengan sendirinya. Karakter peduli lingkungan dilakukan karena ia mencintai lingkungannya. Peduli sosial dilakukan karena ia mencintai masyarakat. Bershahabat dilakukan karena ia mencintai sesama. Semangat kebangsaan dilakukan karena ia mencintai bangsa dan negaranya. Cinta tanah air dilakukan karena ia mencintai tanah kelahirannya. Rasa ingin tahu dilakukan karena ia mencintai pengetahuan. Senang membaca dilakukan karena ia mencintai wawasan yang ia peroleh saat membaca, dan lain sebagainya.

Dengan karakter cinta ini diharapkan lulusan sekolah dapat mencintai kedua orangtuanya yang dimanifestasikan melalui aktivitas seperti mendoakan keduanya, berbakti kepada keduanya, menghormati dengan berkata halus dan sopan serta menyayanginya.

Jika seorang cinta kepada saudaranya maka dapat dimanifestasikan melalui aktivitas mencintai saudara seperti mencintai diri sendiri, menjaga sopan santun dan rendah hati kepadanya, menepati janji, membantu keperluannya, menjaga kehormatan dan nama baiknya, menjaga silaturahim, menghilangkan buruk sangka, menutup aib saudara, dan menghindarkan sikap menganiaya, menghina, mendustakan, meremehkan dan buruk sangka kepada mereka. 
Jika seorang cinta kepada tetangganya maka dapat dimanisfestasikan dengan beberapa tindakan seperti memuliakan dan menghormati tetangga, menolong jika memohon pertolongan, menengoknya jika sakit, mengucapkan selamat jika tetangga memperoleh kebahagiaan, memberi nasihat jika meminta nasihat, saling menanyai kabarnya, mengucapkan salam jika bertemu, saling memberi walaupun sedikit, dan memaafkan jika mereka bersalah.

Cinta kepada lingkungan dapat dimanifestasikan dengan upaya memelihara pelestarian alam seperti melakukan penghijauan, memberi makanan kepada binatang yang dijumpai, melarang penebangan pohon secara liar dan melarang perburuan binatang secara liar.

Manakala karakter cinta terhujam kuat dalam pribadi seseorang, maka dapat menimbulkan berbagai sikap atau akhlak yang lain seperti pemurah, penolong dan pemaaf. Tiga sifat itu identik dengan pengorbanan. Jika masyarakat sudah haus akan pengorbanan maka itu adalah salah satu ciri akan bangkitnya suatu peradaban sebagaimana bangkitnya peradaban Islam di Madinah.

Sikap kasih sayang dan saling mencintai telah dicontohkan oleh kaum Muhajirin dan Anshar. Umat Islam seharusnya saling melengkapi dan menguatkan sehingga kokoh seperti bangunan. Ada yang jadi pasirnya, ada yang jadi semennya, bahkan ada yang jadi pakunya.

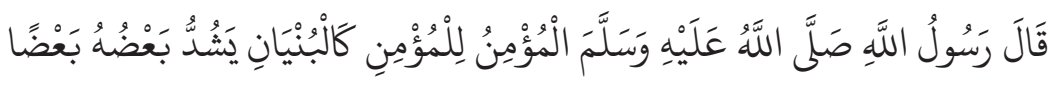

Rasulullah SAW.. bersabda: "Seorang mukmin terhadap mukmin yang lain adalah seperti sebuah bangunan di mana bagiannya saling menguatkan bagian yang lain." (Shahih Muslim, no. 4684).

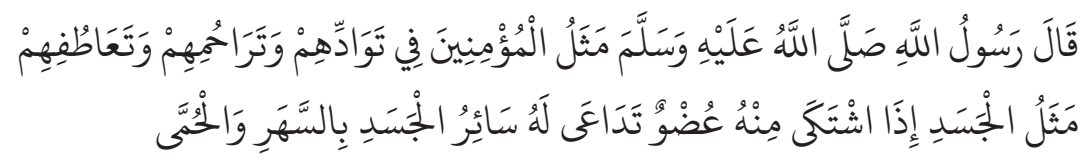

Rasulullah SAW.. bersabda: "Perumpamaan orang-orang mukmin 
dalam hal saling kasih, saling menyayang dan saling cinta adalah seperti sebuah tubuh, jika salah satu anggotanya merasa sakit, maka anggotaanggota tubuh yang lain ikut merasakan sulit tidur dan demam." (Shahih Muslim, no. 4685).

Umat Islam seharusnya saling mencintai, mengasihi dan tolong menolong. Umat Islam janganlah seperti buih dilautan. Jumlahnya banyak tapi tidak punya daya, dipermainkan oleh gelombang, dihempaskan ke kiri dan ke kanan, hanyut dalam arus bukan menciptakan arus, bukan membentuk mode tapi mengikuti mode.

Maka dari itu, jika ingin membenahi suatu peradaban maka mulailah dari pendidikan. Para siswa diharapkan memiliki karakter yang kuat seperti karakter sahabat Rasulullah SAW. sehingga hidupnya dipenuhi dengan rasa cinta dan pengorbanan.

Adapun penelitian mengenai metode pengajaran yang digunakan Rasulullah SAW. dalam mendidik karakter shahabat sebagai berikut:

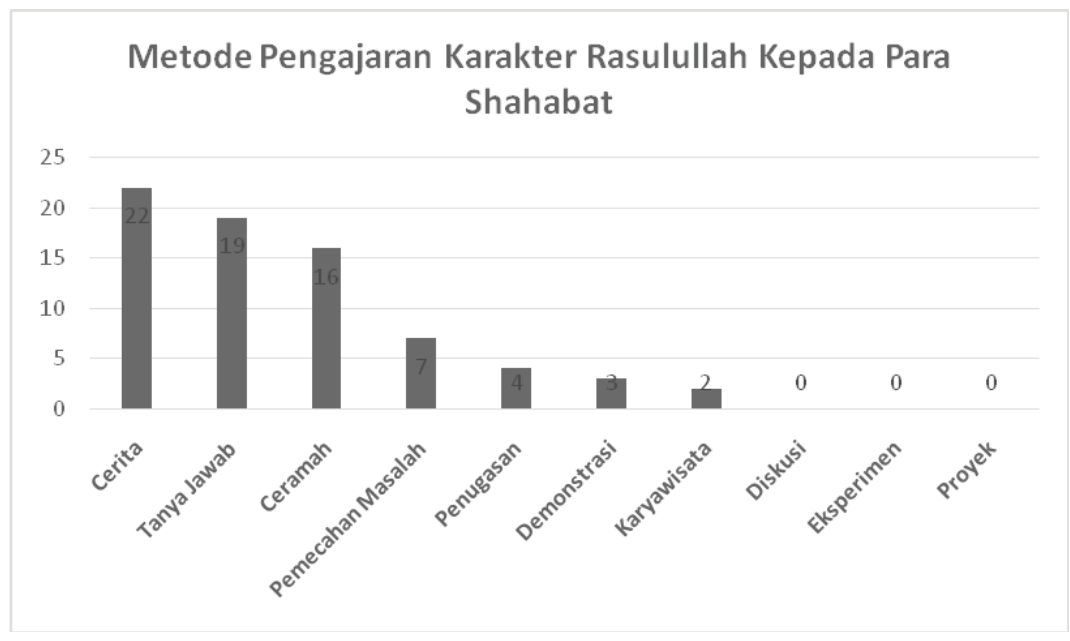

Gambar 4

Metode Pengajaran Karakter yang di gunakakan Rasulullah SAW.

Metode bercerita berjumlah 22 hadits, metode tanya jawab 19 hadits, metode ceramah 16 hadits, metode pemecahan masalah 7 
hadits, metode penugasan 4 hadits, metode demonstrasi 3 hadits, metode karyawisata 2 hadits, metode diskusi 0 hadits, metode eksperimen 0 hadits, metode proyek 0 hadits.

Dari 73 hadits yang diteliti, ditemukan bahwa Rasulullah SAW. menggunakan metode pengajaran yang juga digunakan oleh para guru di sekolah dasar. Tetapi hanya tujuh metode pengajaran yang digunakan Rasulullah SAW. dalam mengajarkan karakter kepada para shahabat, sedangkan tiga metode pengajaran yang lain tidak digunakan yaitu metode diskusi, eksperimen dan proyek. Metode ini tidak digunakan dalam pengajaran karakter, mungkin metode ini cocok pada materi sains atau pada pelajaran yang membutuhkan penemuan baru dan sejenisnya.

Hasil penelitian juga memperoleh data bahwa metode pengajaran karakter yang paling banyak digunakan Rasulullah SAW. dalam pendidikan karakter shahabat adalah metode cerita, tanya jawab dan ceramah.

\section{IMPLEMENTASI DI SEKOLAH}

Perlu diketahui bahwa Rasulullah SAW. berhasil menggunakan metode pengajaran karakter dikarenakan banyak faktor. Apa saja faktor itu dan bagaimana mengimplementasikannya pada proses pendidikan karakter di sekolah:

\section{Guru}

Faktor guru merupakan faktor yang paling penting dalam menggunakan metode pengajaran karakter ini. Maka dari itu diharapkan para guru menjalankan peran sebagai berikut:

\section{a. Menggunakan metode pengajaran karakter yang efektif}

Hasil penelitian ini memperoleh data bahwa metode yang paling banyak digunakan Rasulullah SAW. dalam pendidikan karakter adalah metode cerita, tanya jawab dan ceramah. 
Tiga metode ini harus menjadi metode utama dalam proses pendidikan karakter di sekolah. Metode ini harus dimasukkan kedalam Rencana Pelaksanaan Pembelajaran (RPP) ketika guru ingin mengajar karakter. Adapun empat metode yang lain dijadikan sebagai metode penguat dalam proses pembelajaran dan digunakan pada saat dibutuhkan. Seperti metode penugasan digunakan ketika guru ingin melakukan pembiasaan atau latihan kepada siswa. Metode pemecahan masalah dilakukan ketika menemukan suatu permasalahan dilapangan ataupun di dalam kelas baik yang terencana maupun tidak terencana yang menuntut penyelesaian. Metode demonstrasi dibutuhkan jika ada materi yang membutuhkan gerak atau gambar visual agar lebih mudah dipahami siswa, dan metode karyawisata dilakukan dipertengahan masa studi atau di akhir masa studi sebagai kegiatan luar sekolah untuk menyaksikan langsung permasalahan-permasalahan yang ada.

Kenapa tiga metode tersebut sangatlah penting?. Karena pembentukan karakter itu sifatnya doktriner dan dogmatis tidak demokratis. Pendekatan semacam ini membuat pendidikan karakter lebih cenderung pada pengajaran benar atau salah. Berlaku jujur itu benar dan berbohong itu salah. Berbeda dengan metode diskusi, eksperimen dan proyek yang lebih mengedepankan pembelajaran demokratis dan logis.

Walaupun sifatnya doktriner dan dogmatis bukan berarti proses pengajaran menjadi kaku, menegangkan dan menakutkan bagi siswa. Seorang guru dapat menggunakan metode pengajaran ini dengan menarik, kreatif dan inovatif disesuaikan dengan tuntutan zaman bahkan bisa bercerita dengan menggunakan power point, CD, film, animasi, boneka dan lain sebagainya. Yang penting esensi dari itu semua adalah menggunakan metode bercerita.

Dengan metode cerita, tanya jawab dan ceramah bukan hanya mengantarkan siswa kepada pengetahuan kognitif 
saja tetapi lebih dari itu, yaitu bagaimana siswa merasakan, menyakini dan mencintai suatu karakter. Maka dari itu seorang guru harus pintar bercerita, menguasai teknik tanya jawab dan berlatih retorika.

\section{b. Menjadi teladan bagi siswa}

Peneliti menyimpulkan bahwa esensi dari kajian kebajikan, silaturahim dan adab dalam kitab Shahih Muslim ada tiga yaitu cinta, bersahabat dan peduli. Maka guru yang berkarakter menurut tinjauan hadits-hadits tersebut adalah guru yang memiliki karakter cinta, bersahabat dan peduli.

Guru yang memiliki karakter cinta adalah guru yang suka bersilaturahim (Shahih Muslim, no. 4640), tidak mendengki, membenci dan bermusuhan (Shahih Muslim, no. 4641), tidak berprasangka buruk, apalagi mencaricari aib dan menjerumuskan orang lain (Shahih Muslim, no. 4646), selalu menganjurkan untuk berdamai (Shahih Muslim, no. 4652), tidak mencaci maki (Shahih Muslim, no. 4688), selalu memaafkan dan tidak membalas kejahatan orang (Shahih Muslim, no. 4689), bersikap lemah lembut dan ramah (Shahih Muslim, no. 4697), tidak mengutuk/ melaknat manusia atau hewan (Shahih Muslim, no. 4701), tidak menghukum seseorang tanpa ada alasan syar'i (Shahih Muslim, no. 4733), dan selalu mendoakan orang lain dengan rahmat dan pahala (Shahih Muslim, no. 4705).

Karakter guru yang bersahabat adalah guru yang bersahabat dengan orang-orang sholeh (Shahih Muslim, no. 4762), tidak suka ghibah (Shahih Muslim, no. 4690), berupaya membujuk orang jahat agar menjadi orang baik (Shahih Muslim, no. 4693), tidak akan tidak menyapa lebih dari tiga hari (Shahih Muslim, no. 4643), dan selalu menampakkan keceriaan saat berjumpa (Shahih Muslim, no. 4760).

Karakter guru yang peduli adalah selalu menghilangkan hal yang membahayakan di jalan (Shahih Muslim, no. 4743, 
4745), tidak menyiksa binatang dan sejenisnya (Shahih Muslim, no. 4749), sering menjenguk orang sakit (Shahih Muslim, no. 4660, 4661) berbuat baik kepada anak-anak (Shahih Muslim, no. 4763), tidak bebuat dzalim (Shahih Muslim, no. 4677), dan selalu memberikan pertolongan dalam perkara yang tidak haram (Shahih Muslim, no. no. 4761).

Keberhasilan Rasulullah SAW. dalam pendidikan karakter bukan hanya penguasaan beliau akan penggunaan metode pengajaran tetapi disebabkan karena beliau menjadikan dirinya sebagai teladan bagi para shahabat. Dengan demikian, para shahabat mudah dalam meniru karakter dan kepribadian Rasulullah SAW.

Guru ketika ingin mengajarkan karakter kepada siswa maka guru harus berkarakter terlebih dahulu. Rasulullah SAW. ketika memerintahkan manusia melakukan kebaikan maka beliau adalah orang yang paling pertama kali melakukannya. Ketika beliau melarang manusia dari keburukan maka beliau adalah orang yang pertama kali menghindari dan menjauhinya.

Guru bukan hanya mencerminkan suatu profesi, tetapi merupakan representasi dari berbagai kedudukan yang sangat mulia. Dia adalah pahlawan tanpa pamrih, pahlawan tanpa tanda jasa, pembangun karakter, pembangun peradaban dan sebagainya. Seluruh gambaran ini mencerminkan betapa agung, mulia dan terhormatnya kedudukan seorang guru. Sehingga sosoknya memiliki berbagai atribut yang sangat lengkap dengan berbagai gelar kebaikan. Keteladanan yang diberikan guru akan berdampak besar terhadap kepribadian dan karakter siswa, karena guru adalah pihak kedua setelah orang tua dan keluarga yang paling banyak bersama dan berinteraksi dengan siswa, sehingga sangat berpengaruh bagi perkembangan seorang siswa. 
Siswa memiliki kecenderungan untuk mencontoh. Mereka akan mengamati apa yang dilakukan oleh orangorangyang ada disekitarnya, kemudian mencoba melakukan hal yang sama. Mereka akan terus meniru apa yang mereka lihat, dan menyimpan apa yang mereka dengar. Perilaku guru dalam mengajar, secara langsung atau tidak langsung, akan mempengaruhi motivasi siswa, baik yang sifatnya positif maupun negatif. Jika kepribadian yang ditampilkan guru dalam mengajar sesuai dengan segala kebaikan tutur kata, sikap, dan perilakunya, maka siswa akan termotivasi untuk melakukan hal baik. Sikap dan tingkah laku seorang guru jauh lebih efektif dibanding dengan perkataan yang tidak dibarengi dengan amal nyata.

\section{c. Mengajar dengan cinta, bersahabat dan peduli kepada siswa}

Selain keteladanan, faktor lain yang membuat Rasulullah SAW. berhasil dalam pendidikan karakter adalah faktor kecintaan, persahabatan dan kepedulian.

1) Mengajar dengan cinta

Mengajar dengan cinta adalah mengajar dengan sikap, perkataan, dan tindakan guru yang mencerminkan kasih sayang, sehingga menyebabkan siswa merasa senang dan aman atas kehadiran dirinya.

Guru mengajar dengan cinta dilakukan antara lain dengan terus menyambung tali silaturahim dengan siswa dan orangtuanya dengan tidak memutuskannya. (Shahih Muslim, no. 4638). Tidak mendengki, membenci dan bermusuhan dengan siswa(Shahih Muslim, no. 4641). Tidak berprasangka buruk, mencari-cari aib siswanya bahkan menjerumuskannya (Shahih Muslim, no. 4646).

Tidak menzhalimi, mendengki, membenci, memalingkan wajah, menghina, meremeh, dan menginjak kehormatan siswanya (Shahih Muslim, no. 
4650). Seorang guru juga dilarang untuk tidak menyapa siswanya (Shahih Muslim, no. 4652).Guru hendaknya mengajar dengan cinta kepada siswanya yang didasarkan pada kecintaan kepada Allah Swt. (Shahih Muslim, no. 4656). Seorang guru juga dianjurkan untuk melapangkan kesusahan, menutupi aib dan kesalahan siswanya (Shahih Muslim, no. 4678). Guru hendaklah mencintai siswanya dalam hal saling kasih, saling menyayang dan saling cinta seperti sebuah tubuh, jika salah satu anggotanya merasa sakit, maka anggotaanggota tubuh yang lain ikut merasakan sulit tidur dan demam (Shahih Muslim, no. 4685), sehingga kecintaan antara guru dan murid seperti sebuah bangunan di mana mereka saling menguatkan (Shahih Muslim, no. 4684). Seorang guru juga dilarang mencaci maki siswanya (Shahih Muslim, no. 4688). Seorang guru di anjurkan untuk memberikan maaf daripada harus membalas keburukan atau kejahatan siswanya dan seorang guru harus bersikap tawadhu atau rendah hati (Shahih Muslim, no. 4689). Seorang guru tidak boleh menghukum siswanya tanpa ada alasan syar'i(Hadits Shahih, no. 4733). Seorang guru harus bersikap ramah dan lemah lembut kepada siswanya (Shahih Muslim, no. 4697). Guru dilarang mengutuk dan melaknat siswanya, karena tidak boleh seorang yang muslim itu menjadi tukang kutuk (Shahih Muslim, no. 4701). Seorang guru hendaknya mendoakan agar siswanya mendapat pahala dan rahmat dari Allah Swt (Shahih Muslim, no. 4705, 4712).

2) Bersahabat dengan siswa

Guru yang bersahabat/ Komunikatif adalah guru yang segala tindakannya memperlihatkan rasa senang berbicara dan bergaul dengan siswanya.

Ciri guru yang bersahabat adalah guru yang selalu menyapa siswa-siswanya dan jika tidak menyapa maka 
tidak lebih dari tiga hari. Boleh seorang guru tidak menyapa siswanya pada tiga hari itu karena alasan kuat dalam rangka mendidik siswa. Karena secara naluriah manusia memiliki sifat marah, tempramental, dan lainnya. Tetapi Rasulullah SAW. melanjutkan haditsnya bahwa yang terbaik ialah orang yang memulai mengucapkan salam (Shahih Muslim, No. 4643). Guru yang bershahabat tidak melakukan ghibah. Ghibah adalah menceritakan tentang siswanya saat ia tidak ada, dengan sesuatu yang dapat menyakitkannya (Shahih Muslim, no. 4690). Guru yang bersahabat membujuk siswa yang ditakuti kejahatannya agar hatinya menjadi lunak (Shahih Muslim, no. 4693). Selalu menampakkan keceriaan saat berjumpa dengan siswa (Shahih Muslim, no. 4760). Guru yang bersahabat adalah guru yang mengajurkan siswa-siswanya untuk bergaul dan bersahabat dengan kawan-kawan yang baik bukan kawan yang jahat (Shahih Muslim, no. 4762).

3) Peduli terhadap siswa

Guru yang peduli kepada siswanya adalah guru yang segala sikap dan tindakannya selalu ingin memberi bantuan kepada siswa yang membutuhkannya.

Guru yang peduli adalah guru yang menjenguk siswanya kala sakit (Shahih Muslim, no. 4660, 4661). Tidak kikir kepada siswa (Shahih Muslim, no. 4675). Membantu keperluan, melapangkan kesusahan dan memberikan pertolongan kepada siswa (Shahih Muslim, no. 4677, 4761). Termasuk peduli terhadap siswa adalah dengan membantu siswa-siswa yang kurang mampu dengan membiayai mereka dan bersabar mengurus segala urusannya (Shahih Muslim, no. 4763,4765$)$.

Peduli merupakan sikap guru yang didasari pada keprihatinan terhadap siswa. Guru melibatkan diri 
dalam persoalan, keadaan atau kondisi yang terjadi pada siswa. Tentu hal ini dilakukan dalam rangka memberikan inspirasi, perubahan dan kebaikan kepada siswanya.

Mahmud Yunus mengatakan dalam bukunya atTarbiyah wa Ta'lim:

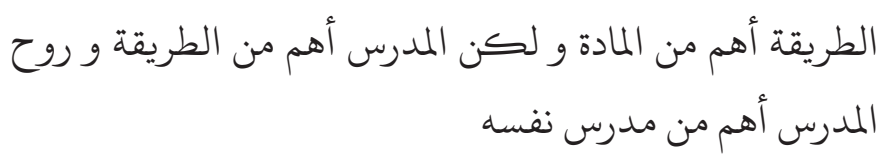

Metode itu lebih penting dari materi akan tetapi guru itu lebih penting dari metode dan jiwa guru jauh lebih penting dari dirinya sendiri.

Mahmud Yunus memberi nasihat kepada calon guru bahwa penguasaan akan materi pelajaran itu penting tetapi metode untuk mempengaruhi siswa agar tercapai tujuan pengajaran itu juga penting untuk dipelajari. Tapi faktor guru dalam hal keteladanan lebih penting dari metode pengajaran dan ruh seorang guru jauh lebih penting dari keteladanan guru itu sendiri. Ruh ini mungkin berupa kecintaan, persahabatan dan kepedulian guru kepada siswanya.

Jika guru mengajarkan karakter kepada siswa dengan metode pengajaran karakter yang efektif kemudian diiringi dengan keteladanan dan mengajar dengan cinta, bersahabat dan peduli maka insya Allah akan lahir generasi Muslim yang berkarakter.

\section{Bahan Pengajaran}

Bahan pengajaran/ materi yang diajarkan Rasulullah SAW. kepada para shahabat sebagaimana berikut:

1) Materi singkat/ ringkas

2) Bahan pengajaran terdapat unsur cerita dan tanya jawab 


\section{Fasilitas}

Dalam metode cerita, tanya jawab dan ceramah tidak memerlukan banyak fasilitas dalam proses pembelajaran, berbeda dengan metode eksperimen dan proyek. Dalam metode cerita hanya dibutuhkan alat bantu sederhana seperti boneka, baik boneka manusia maupun binatang, perangkat simulasi seperti tempat duduk dan meja kecil-kecil, dan sebagainya. Bisa juga berupa gambar atau power point yang di tayangkan melalui LCD di tembok sekolah.

\section{Siswa}

Proses pendidikan karakter di sekolah bagi siswa membutuhkan tiga hal:

1) Penyeleksian siswa dan penetapan standar kompetensi lulusan

Sekolah perlu menyeleksi siswa di awal tahun agar guru dapat mengetahui kualitas atau kemampuan siswa dalam belajar, sehingga guru dengan mudah dapat memilih metode pengajaran yang tepat untuk siswanya. Rasulullah SAW. pernah menggunakan metode tanya jawab kepada seorang Arab badui yang baru masuk Islam dengan memberikan jawaban yang sesuai dengan kemampuannya (Shahih Muslim, no. 4775). Peneliti menyarankan agar memasukkan dalam SKL, target lulusan yang memiliki kepribadian/berkarakter cinta, bersahabat dan peduli kepada orang lain.

2) Penegakan Aturan

Beberapa hal yang harus diperhatikan ketika guru hendak membuat peraturan dan tata tertib di kelas, sebagai berikut:
a) Bisa dimengerti
b) Bisa dilaksanakan
c) Tidak terlalu banyak
d) Tegas, adil dan konsisten 
3) Pembiasaan

Pembiasaan dalam proses pendidikan karakter banyak menggunakan metode penugasan walaupun tidak seluruhnya. Rasulullah SAW. pun melakukan pembiasaanpembiasaan kepada shahabatnya. Sebagaimana penugasan Rasulullah SAW. sahabatnya yang bernama Abu Barzah agar menyingkirkan hal-hal yang membahayakan kaum muslimin di tengah jalan (Shahih Muslim, no. 4747). Perintah Rasulullah SAW. kepada para shahabat agar berhati-hatimembawa senjata tajam ketika berada ditempat keramaian (Shahih Muslim, no. 4736). Rasulullah SAW.juga menganjurkan kepada Abu Dzar agar memperbanyak kuah kalau memasak lauk pauk dan membagikannya kepada tetangganya (Shahih Muslim, no. 4758) dan Rasulullah SAW. pernah didatangi seseorang untuk suatu keperluan, lalu Rasulullah SAW. menghampiri para shahabat yang sedang berkumpul, dan memerintahkan untuk membantu saudaranya yang sedang dalam keperluan (Shahih Muslim, no. 4761). Penugasan yang dilakukan Rasulullah SAW. kepada para shahabat sebagai bentuk pembiasaan kepada mereka agar berkarakter cinta, bersahabat dan peduli kepada sesama.

\section{B. KESIMPULAN}

Berdasarkan hasil penelitian pada pembahasan sebelumnya, maka dapat disimpulkan sebagaimana berikut:

1. Metode pengajaran karakter yang digunakan Rasulullah SAW. kepada para shahabat dalam kitab Shahih Muslim.

Penelitian ini memperoleh data bahwa metode yang paling banyak digunakan Rasulullah SAW. adalah metode cerita, tanya jawab, dan ceramah. Beliau SAW. juga menggunakan metode pemecahan masalah, penugasan, demonstrasi dan karyawisata tetapi tidak menggunakan metode diskusi, eksperimen dan proyek dalam proses pengajaran karakter kepada para shahabat. 
2. Implementasinya pada proses pendidikan karakter di sekolah

Guru sebagai faktor utama dalam pengajaran karakter di kelas harus menguasai metode cerita, tanya jawab dan ceramah. Guru hendaknya mengajar dengan penuh cinta, bershahabat, peduli dan menjadi teladan bagi siswa. Bahan pengajaran yang digunakan sebaiknya singkat namun padat makna serta terdapat unsur cerita dan tanya jawab. Fasilitas pembelajaran disesuaikan dengan kebutuhan. Siswa agar diseleksi untuk mengetahui kemampuan mereka, menetapkan standar kompetensi lulusan, menegakkan aturan kelas dan menerapkan pembiasaan-pembiasaan baik bagi siswa.[]

\section{DAFTAR PUSTAKA}

Ulil Amri Syafri, Pendidikan Karakter Berbasis al-Qur'an, Jakarta: PT RajaGrafindo Persada, 2012.

Sofyan Sauri, Filsafat dan teosofat Akhlak (kajian filosofis dan teosofis tentang akhlak, karakter, nilai, moral, etika, budi pekerti, tatakrama, dan sopa santun), Bandung: Rizqi Press, 2011.

Departemen Agama, Al-Qur'an dan Tafsirnya, Jilid 9, Jakarta: Departemen Agama RI, 2009.

http://mizan.com/news_det/wow-anak-smk-di-mataram-jagomerakit-laptop-and-lcd.html 10 Maret 2013.

Amal Fatkhullah, Tawuran Pelajar, dalam Abudin Nata, Kapita Selekta Pendidikan Islam, Bandung: Penerbit Angkasa, 2003.

http://m.tvonenews.tv/read.htmlid=62132 27/09/2012.

Sofyan Sauri, Pendidikan Berbahasa Santun, Bandung: PT Genesindo, 2006.

Wendi Zarman, Ternyata Mendidik Anak Cara Rasulullah itu Mudah dan Lebih Efektif, Jakarta: Penerbit Ruang Kata, 2011. 
Wendi Zarman, Ternyata Mendidik Anak Cara Rasulullah itu Mudah dan Lebih Efektif, Jakarta: Penerbit Ruang Kata, 2011.

Erry Utowo et. Al., Pengembangan pendidikan Budaya dan Karakter Bangsa, Jakarta: Pusat Kurikulum Kementrian Pendidikan Nasional, 2010.

Abd al-Rahman Abd al-Khiq, al-Fikr al-Shufi fi Dhau al-Kitab wa alSunnah, Kuwait: Maktabah Ibn Taimiyah, 1986.

Abuddin Nata, Perspektif Islam tentang Strategi Pembelajaran, Jakarta: Kencana Prenada Media Group, 2009.

Wendi Zarman, Mendidik Anak Cara Rasulullah, Bandung: Penerbit Ruang Kata, 2011.

Aminuddin Rasyad, Teori Belajar dan Pembelajaran, Jakarta: Uhamka Press, 2003.

Ahmad Tafsir, Ilmu Pendidikan dalam Perspektif Islam, Bandung: Penerbit PT Remaja Rosdakarya, 2010.

Samsul Nizar (ed), Sejarah Pendidikan Islam (Menelusuri Jejak Sejarah Pendidikan Era Rasulullah Sampai Indonesia),Jakarta: Kencana, 2009.

Muhammad Alfis C, Indeks Hadits dan Syarah, Jakarta: CV. Alfonso Pratama, 2008.

Kafrawi Ridwan, Ensiklopedi Islam, Jakarta: PT Ikhtiar Baru Van Hoeve, 1994. 